\title{
Irish Home Rule and Constitutional Reform in the British Empire, 1885-1914
}

Home Rule irlandais et réforme constitutionnelle dans l'Empire britannique, 1885-1914

Thomas Mohr

\section{OpenEdition}

\section{Journals}

Electronic version

URL: https://journals.openedition.org/rfcb/3900

DOI: $10.4000 /$ rfcb.3900

ISSN: 2429-4373

Publisher

CRECIB - Centre de recherche et d'études en civilisation britannique

Electronic reference

Thomas Mohr, "Irish Home Rule and Constitutional Reform in the British Empire, 1885-1914", Revue Française de Civilisation Britannique [Online], XXIV-2 | 2019, Online since 19 juin 2019, connection on 28 juin 2022. URL: http://journals.openedition.org/rfcb/3900 ; DOI: https://doi.org/10.4000/rfcb.3900

This text was automatically generated on 29 September 2020 .

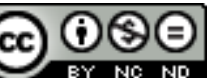

Revue française de civilisation britannique est mis à disposition selon les termes de la licence Creative Commons Attribution - Pas d'Utilisation Commerciale - Pas de Modification 4.0 International. 


\section{Irish Home Rule and Constitutional Reform in the British Empire, 1885-1914}

Home Rule irlandais et réforme constitutionnelle dans l'Empire britannique, 1885-1914

Thomas Mohr

\section{Introduction}

1 When Prime Minister William E. Gladstone committed himself and his ruling Liberal party in 1885 to Irish home rule, a form of autonomy for Ireland while remaining an integral part of the United Kingdom, he was embarking on an unprecedented constitutional experiment. The origins of this proposal can be traced back to 1870 when Isaac Butt, an Irish lawyer, called a public meeting in which he proposed the creation of an autonomous parliament for Ireland within the United Kingdom that would pass laws on local matters. ${ }^{1}$ Butt also produced a pamphlet in 1870 entitled Irish Federalism, in which he promoted his idea by arguing: "It offers to England an opportunity of conciliating the Irish people without making concessions which would involve revolutionary changes or endanger the stability of the Empire". ${ }^{2}$ Butt's proposal evolved over the course of the 1870 s and gradually became known as "home rule". It came to inspire a political movement in Ireland that would, in turn, lead to the emergence of a political party known as the Irish parliamentary party or sometimes as simply the home rule party. This party won 59 parliamentary seats in the 1874 general election and would win more under charismatic leaders that succeeded Isaac Butt, in particular Charles Stewart Parnell. ${ }^{3}$ In late 1885 William E. Gladstone, who had once had little interest in home rule, publicly changed his position to one of outright support. ${ }^{4}$ In 1886 the support of the Irish parliamentary party ensured that he became Prime Minister and formed a government committed to granting home rule to Ireland. Gladstone took it upon himself to draft the bill that many hoped would turn this dream into reality. 
2 The first problem that Gladstone faced in 1886 was discovering what precisely "home rule" actually meant. Isaac Butt had provided a short outline of the powers of his anticipated Irish parliament in his 1870 pamphlet but he had died in 1879 and Gladstone's anticipated legislation required a far more detailed scheme. Many Irish nationalists in this period still wanted to restore the old Irish parliament that had existed since the Middle Ages and had been brought to an end in 1801 by the Irish Act of Union. ${ }^{5}$ This parliament had enjoyed significant autonomy in its last years of life, a period from 1782 to 1801 in which it would be known as "Grattan's parliament" after Henry Grattan, one of the leading figures in the Irish parliament in these years. ${ }^{6}$ However, there was a tendency among Irish nationalists in the $19^{\text {th }}$ century to romanticise Grattan's parliament and its many failings were largely forgotten. These failings included a history of corruption and a complete ban on Catholic membership. The practical limits on the autonomy of Grattan's parliament were also greater than many later Irish politicians liked to admit. ${ }^{7}$

3 It was clear to informed supporters of Irish autonomy that something entirely new was required. In 1886 Gladstone examined federal models in Europe and North America in the hope of discovering a suitable model for Irish autonomy within the United Kingdom. These included the unions between Austria and Hungary, Sweden and Norway, Denmark and Iceland, Russia and Finland and others. He also examined the federal union of the states within the United States of America. The model that finally captured his attention was one that was reassuringly British, or at least lay within the embrace of the British Empire. This was the confederation of the provinces of Canada that was brought into being by a statute passed at Westminster known as the British North America Act 1867. Gladstone made extensive use of the 1867 Act during the drafting of the first Irish home rule bill, known officially as the Government of Ireland Bill, that was presented to parliament in 1886. By the end of the drafting process Gladstone's copy of the British North America Act was heavily defaced with key phrases underlined and many annotations in the margins. ${ }^{8}$ The heavy reliance on the British North America Act was also evident in the structure and contents of the Government of Ireland Bill. ${ }^{9}$ Historical analogies with Canada were also useful in justifying this attempt to grant greater autonomy to Ireland. It was argued that Canada had been a restless part of the British Empire in the middle of the $19^{\text {th }}$ century but the granting of greater autonomy and selfgovernment had pacified it and even turned rebels into loyalists. For example, in 1870 Isaac Butt concluded, "Why should not the self-government which has made Canada contented and loyal be equally successful in Ireland in attaining the same results?". ${ }^{10}$

The debates surrounding the Government of Ireland Bill 1886 firmly established the link with Canada in political discourse on Irish home rule. For example, The Times summarised Gladstone's policy on Irish home rule as being one of "Ireland as Canada". ${ }^{11}$ The 1886 Bill was defeated in the House of Commons but subsequent attempts at Irish home rule largely reproduced its structure and provisions. Another Government of Ireland Bill was passed by the House of Commons in 1893 but defeated in the House of Lords. A third attempt proved to be successful and the Government of Ireland Act 1914 was duly enacted by the parliament at Westminster but was suspended with the outbreak of the First World War. ${ }^{12}$ Analogies with Canada and the autonomy enjoyed by other colonies of white settlement, known as "Dominions", remained a common feature of the debates on home rule between 1885 and 1914. 


\section{Home Rule and Dominion status}

5 In 1867 the provinces of Ontario, Quebec, New Brunswick and Nova Scotia were united to become the "Dominion of Canada" ${ }^{13}$ It was anticipated that the remaining provinces in British North America would join the new confederation and most did in the years that followed..$^{14}$ The British provinces of North America had been slowly attaining greater autonomy from the United Kingdom and this process accelerated after 1867.

The model pioneered in Canada of gradual evolution towards greater autonomy while remaining within the British Empire proved such a success that it was soon exported to other British colonies of white settlement. Canada soon became known as the "eldest Dominion" and was joined by newer Dominions such as Australia (1901), New Zealand (1907) and South Africa (1910). ${ }^{15}$ Some Dominions were federal unions, such as Canada and Australia while others were unitary states, such as New Zealand and South Africa. Both types of Dominion enjoyed identical status in their relationship to the United Kingdom and in their position within the Empire. Newfoundland was recognised as a separate Dominion in the early $20^{\text {th }}$ century although it was often assumed that its destiny lay in eventually becoming a province of the federated Dominion of Canada, a prediction that finally came true in $1949 .{ }^{16}$ The conceptual separation of the Dominions from the colonies that lacked powers of self-government was recognised in the increased popularity of the term "British Commonwealth" to describe the special association between the United Kingdom and the Dominions within the broader framework of the British Empire. ${ }^{17}$

7 The model pioneered in Canada became known as "Dominion status". The precise meaning of Dominion status was never legally defined because it was an evolving status of autonomy from the United Kingdom as the "mother country" of the British Empire. The absence of a legal definition of Dominion status was even celebrated by one English attorney general on the grounds that it was "a thing of life, of spirit, and growing, and not a dead thing of legal form". ${ }^{18}$ As a result, textbooks on public international law in the early 20th century were often uncertain as to how to class the Dominions and often placed them in a category of their own as entities with greater sovereignty than a colony but not quite the level of sovereignty enjoyed by sovereign states. ${ }^{19}$ This only changed after 1931 when London consented to the enactment of the Statute of Westminster which gave the Dominions sufficient powers to enable scholars of public international law to finally consider them as being sovereign states. ${ }^{20}$

Much of the expansion of Dominion status in terms of geography and sovereignty still lay in the future in the late $19^{\text {th }}$ century. When the concept of Irish home rule was first proposed the only Dominion in existence was Canada. The use of the Canadian model was evident from the earliest days of the Irish campaign for home rule and grew with the passage of time. ${ }^{21}$ The powerful links between Dominion status and Irish home rule ensured that the two concepts were often treated as if they were virtually identical. ${ }^{22}$ This confusion was unfortunate because there were actually important differences between the two concepts. For example, the anticipated Irish parliament under all the proposals for home rule would not have had the equivalent autonomy enjoyed by the Dominions in the important spheres of defence, taxation, currency and trade. T.P. O'Connor, a longserving member of the Irish parliamentary party, noted the persistent confusion between proposals for Irish home rule and Dominion status in Canada and concluded: 
Canada has full fiscal liberty, she has the right to raise a navy, she has practically complete self-government. She sends representatives to other Powers to make treaties. Under no system of Home Rule that has ever been proposed by an Irish leader have we even thought of anything approaching these powers. ${ }^{23}$

In short, Canada and the other Dominions were autonomous parts of the British Empire, whereas Ireland, under a home rule settlement, would have been an autonomous part of the United Kingdom. The Dominions were given ambiguous recognition in textbooks on international law in the late $19^{\text {th }}$ and early $20^{\text {th }}$ centuries whereas Ireland under a home rule settlement would not have merited any recognition in such a text.

Why did most Irish nationalists support the objective of home rule before 1914 if Dominion status offered much greater autonomy than home rule? In fact, a few scholars and politicians did propose Dominion status for Ireland in this period but the absence of support from a significant political or intellectual movement ensured that their words had limited impact. ${ }^{24}$ Dominion status for Ireland was not seen as a realistic proposal that London might be prepared to consider in this period. T.P. O'Connor concluded "Sometimes we are described as wanting the same thing as the Dominion of Canada has. I wish we could get it, but I know we cannot - not in my time, at any rate." ${ }^{25}$ Before 1914 many contemporaries believed that the Dominions were gradually evolving into sovereign states, a position that no British government in London in this period would have been prepared to tolerate in relation to Ireland. ${ }^{26}$

\section{“Home Rule all round"}

11 Additional complications were created by the question of what would happen to the remainder of the United Kingdom if the island of Ireland were granted home rule.

There was a natural perception of imbalance at the prospect of Ireland having autonomy within the United Kingdom while England, Scotland and Wales did not. The solution was to give home rule to all the constituent parts of the United Kingdom and not just Ireland, a proposal that was popularly known as "federal home rule" or more commonly as "home rule all round". ${ }^{27}$

The association between Irish home rule and proposals for a wider federal settlement for the entire United Kingdom was present at the very beginnings of the movement initiated by Isaac Butt. In 1870 Butt proposed Irish home rule in the wider context of a federal United Kingdom with autonomous parliaments in England, Ireland and Scotland while maintaining a parliament for the United Kingdom as a whole in London. ${ }^{28}$ Wales, which had never enjoyed the status of a separate Kingdom in previous centuries, was not included in Butt's proposal and presumably would have been subject to the autonomous parliament for England.

One of the most enthusiastic advocates of home rule all round in the late $19^{\text {th }}$ century was Thomas Allnutt Brassey, later Earl Brassey. Brassey was one of the founders of the Federal Union Committee in 1901 which was dedicated to promoting the constitutional experiment of home rule all round. Unlike Isaac Butt, Brassey was prepared to include Wales, in addition to England, Ireland and Scotland, in his proposed federal schemes. However, the main purpose of this committee was not to win over British public opinion but to convince other members of the Liberal party of the merits of home rule all round. Yet, even this limited objective proved to be out of reach. The committee never achieved 
its objective of making home rule all round one of the official policies of the Liberal party and Brassey's own career within the party never prospered. ${ }^{29}$

Why were the campaigns of Brassey and other advocates of home rule all round so unsuccessful? One barrier was deciding what to do with England whose population far surpassed the combined total of Ireland, Scotland and Wales. Should England be kept as a single unit or split into smaller parts with each enjoying a form of home rule? Similar questions were asked of Ireland itself. The high concentration of opponents of home rule, known as "unionists", in the Irish province of Ulster led to proposals that Ireland be split into two autonomous areas within the United Kingdom. For example, in 1912 Winston Churchill proposed a scheme for a federal United Kingdom that included autonomous parliaments in both Dublin and Belfast..$^{30}$ Some proposals argued that future parliaments in Dublin and Belfast enjoy equal status within the United Kingdom while others suggested that the Belfast parliament should be placed under some form of supervision by the parliament in Dublin, a complex arrangement known as "home rule within home rule". ${ }^{31}$

The objective of home rule all round also attracted powerful opposition, not least from Albert Venn Dicey, the leading scholar of the period on British constitutional law. Dicey believed that the political situation of his day offered a straight choice between maintaining the status quo or constructing a path towards a fully sovereign Irish state. This ensured that he was not only a staunch opponent of proposals for Irish home rule but also condemned the "fallacies of federation" ${ }^{32}$ Dicey saw a fundamental difference between the creation of federal unions in the USA and Canada, which had brought states together, and a future federal scheme for the United Kingdom, which he saw as breaking a state apart. ${ }^{33} \mathrm{He}$ also argued that a federal scheme would make the United Kingdom more vulnerable to attack by a foreign power, an obvious reflection of his distrust of Irish loyalties. ${ }^{34}$ Finally, Dicey recognised that a federal settlement would require a new written constitution which would mean the end of the existing unwritten British constitution, whose merits had been extolled by him throughout his career..$^{35}$

Other serious obstacles included the absence of significant political movements advocating home rule for Scotland, Wales or England in this period. ${ }^{36}$ In addition, there was never a significant political movement wholly dedicated to turning the United Kingdom into a federation or a union of devolved bodies. Proposals for home rule all round remained the preserve of academics and a few enthusiastic politicians and never came close to capturing the imagination of the British electorate in this period.

The challenges facing home rule all round did not prevent it from being combined with proposals for an even more ambitious constitutional experiment. This was called "Imperial federation", a proposal that advocated a federal union between the United Kingdom and the self-governing Dominions. An example of the close relationship between these two constitutional projects can be found in the views of Earl Brassey who, in addition to being one of the foremost supports of home rule all round, was also an Imperial federalist. ${ }^{37}$ Proposals for Irish home rule were often seen as a preliminary to creating a federal United Kingdom while a federal United Kingdom was often seen as a preliminary to creating a federal British Empire. ${ }^{38}$ 


\section{Imperial Federation}

19 Imperial federation was a proposed constitutional experiment that had the potential to overcome many of the challenges of Irish home rule while also providing an alternative to the evolution of the Dominions in the direction of becoming sovereign states. The emergence of the Dominions as new centres of power in the late 19th century resulted in ideas for a new form of Imperial governance by means of consensus in place of the previous position of total dominance by the United Kingdom. Although the United Kingdom remained by far the largest entity in the Commonwealth in terms of population and industrial production it was recognised that the rapid growth of the Dominions ensured that this would not always be so. This led to calls in the late $19^{\text {th }}$ and early $20^{\text {th }}$ centuries for the recognition of the Dominions as equal partners in the Commonwealth in a much closer association than existed in that period. The alternative was presented as a future of increased divergence of interests between the United Kingdom and the Dominions which would lead to the end of any form of special relationship between them. Consequently, the unofficial motto of the Imperial federalists was "federate or disintegrate". 39

Several organisations emerged between 1885 and 1914 that campaigned for a future based on Imperial federation. They included the Imperial Federation League, the British Empire League, the Imperial Federation (Defence) Committee and the Round Table movement. Sympathy for the federalist movement went far beyond membership of these organisations and included high profile politicians such as Lord Rosebery, British Prime Minister (1894-1895), John A. Macdonald, Canadian Prime Minister (1867-1873 and 1878-1891), Charles Tupper, Canadian Prime Minister (May to July 1896) and Joseph Chamberlain, British colonial secretary (1895-1903). ${ }^{40}$ Charles Gavan Duffy, an Irish nationalist politician who eventually moved to Melbourne and served as premier of Victoria from 1871 to 1872 , supported the federation of the Australian colonies as a prelude to a wider Imperial federation. ${ }^{41}$

21 Proposals for Imperial federation usually focused on creating some form of federal parliament with representatives from the United Kingdom and the Dominions. In 1885 Sir Julius Vogel, a former premier of New Zealand, proposed the creation of a federal legislature for the British Empire. ${ }^{42}$ In 1897 Joseph Chamberlain advocated the creation of a "Council of the Empire". ${ }^{43}$ Proposals for the creation of some form of federal council were also made at a meeting of the British and Dominion governments in $1902 .{ }^{44}$ Calls for a federal legislature were often combined with proposals for a federal executive and federal courts, although these tended to attract less attention. ${ }^{45}$

The failure of all these initiatives did not dissuade Sir Joseph Ward, Prime Minister of New Zealand (1906-1912 and 1928-1930), from proposing the creation of a federal parliament whose powers would largely have focused on defence and foreign policy at a meeting of the British and Dominion governments in $1911 .{ }^{46}$ Ward proposed a new " Imperial House of Representatives" comprised of 300 elected members each representing 200,000 of the voting population. ${ }^{47}$ The anticipated breakdown of the representatives elected every five years to the proposed parliament was as follows:

United Kingdom - 220

Canada - 37

Australia - 25 
South Africa ${ }^{48}-7$

New Zealand - 6

Newfoundland - 2 federal parliament reflects contemporary realities in which the United Kingdom's population would ensure that it dominated any representative federal institutions. How could such an imbalance be addressed? One solution was to combine Imperial federation with Irish home rule or even home-rule all round. Federal institutions would no longer be dominated by a single political actor if the United Kingdom were divided into smaller parts. This meant that Irish home rule, which was often presented as a potential threat to the British Empire, could be presented as a means to preserving the unity of at least the white-dominated portions of the British Empire. Consequently, calls for Imperial federation were often combined with calls for Irish home rule and/or home rule all round. For example, Julius Vogel declared that home rule for Ireland was of considerable interest to other parts of the British Empire "because of its intimate connection with the larger question of federation of the Empire" ${ }^{49} \mathrm{H} . \mathrm{H}$. Asquith, Prime Minister of the United Kingdom 1908-1916, noted that "out of Irish Home Rule would emerge a vast new scheme of imperial reconstruction". ${ }^{50}$

The best known example of the relationship between Irish home rule and Imperial federation occurred in 1888 when Cecil Rhodes, a wealthy British businessman who had entered politics in South Africa, donated $£ 10,000$ to the Irish parliamentary party. Rhodes made clear that his donation was based on a belief that Irish home rule would increase the prospect of Imperial federation. The donation was accompanied by a letter to Charles Stewart Parnell, then leader of the Irish parliamentary party, in which Rhodes wrote of home rule as a "stepping-stone to that federation, which is the condition of the continued existence of our Empire". ${ }^{51} \mathrm{~T}$ his relationship between Irish home rule and Imperial federation is seldom remembered in $21^{\text {st }}$ century Ireland. Yet, it was perfectly possible for an Irish nationalist such as Charles Gavan Duffy to advocate Imperial federation in the late $19^{\text {th }}$ century. The main reason for the dearth of memory concerning the relationship between Irish home rule and Imperial federation lies in the changed political landscape that emerged after 1914.

\section{Conclusion}

The years between 1885 and 1914 witnessed a great outpouring of proposals for radical constitutional reforms for the United Kingdom and the British Empire. Irish home rule was just one of these proposed reforms but it had deep connections with others such as Imperial federation, home rule all round and the development of Dominion status. The unifying feature of these constitutional projects was their use in arguing that Irish nationalism and support for the continued strength and integrity of the British Empire were not necessarily incompatible concepts. More radical Irish nationalists in this period, for example Patrick Pearse and James Connolly, would have disagreed with such a contention but their perspective would not win mass electoral support until after the conclusion of the First World War. Before 1914 it was possible for Irish nationalist politicians to openly support the preservation of the British Empire. Examples include Isaac Butt, the founder of the home rule movement, and John Redmond, leader of the

Revue Française de Civilisation Britannique, XXIV-2 | 2019 
Irish parliamentary party from 1900 to 1918, who liked to argue that Ireland had played as important a role as England or Scotland in building the British Empire. ${ }^{52}$

Redmond and other members of the Irish parliamentary party argued passionately that Irish home rule would strengthen the Empire and not weaken it. ${ }^{53}$ Their main argument was that home rule, in removing the sense of injustice felt by many Irish people at the abolition of the autonomy that they had enjoyed in previous centuries, would eliminate a major source of discontent within the Empire. They also argued that autonomy would reconcile Irish people to the British Empire as had allegedly occurred in Canada. Arguments that Irish home rule could facilitate home rule all round and Imperial federation were less prominent but were often used by Irish politicians, especially when speaking to audiences outside Ireland.

Of course, the priority of those Irish nationalists who openly favoured the maintenance of the British Empire remained the achievement of Irish home rule. John Redmond admitted that even if it could be proved that home rule for Ireland would actually injure the Empire, a proposition that he never accepted, his party would still demand it. ${ }^{54}$ Such a frank admission of priorities does not necessarily mean that that pro-Empire sentiments within the Irish parliamentary party were insincere. Arguments that Irish home rule would actually strengthen the Empire did succeed in persuading large numbers of British and Dominion politicians who had no connection of any form to Ireland. This is evident in the large numbers of British politicians who were prepared to vote in favour of Irish home rule and in the parliamentary resolutions in support of Irish home rule passed by the Canadian parliament in 1882 and 1903 and passed by the Australian parliament in $1906 .^{55}$

8 In the late $19^{\text {th }}$ and early $20^{\text {th }}$ centuries Irish home rule was seen as a constitutional experiment and opinions remained divided as to whether it would lead to positive or negative outcomes for the British Empire, the United Kingdom or for Ireland itself. In these circumstances, it is important to examine the results of the close relationship between Irish home rule and other constitutional projects such as Imperial federation, home rule all round and Dominion status. This demands some assessment of the relationship between Irish home rule and each of these constitutional projects.

Imperial federation proved to be an unattainable dream. Campaigns for Imperial federation continued and even reached their peak after the outbreak of war in 1914 but events during the war rendered them obsolete. The contribution of the Empire to the British war effort inspired the British government to create an "Imperial War Cabinet" that sat in 1917 and 1918. This involved bringing the Dominion Prime Ministers and representatives from India to London to discuss matters of common interest and, in particular, the ongoing conflict. Although this was an exciting development for Imperial federalists these meetings witnessed a decisive rejection of Imperial federation by British and Dominion representatives. ${ }^{56}$ For example, a meeting in 1917 saw Jan Smuts, Prime Minister of South Africa, declare

To attempt to run by a Central Parliament and a Central Executive even the common concerns [of] a group of nations spread over the whole world, speaking different languages, belonging to different races with entirely different economic circumstances ... is to my mind absolutely to court disaster. ${ }^{57}$

How much enthusiasm did Irish home rule politicians really have for proposals for Imperial federation? In 1888 Parnell made guarded statements in support of Imperial federation while accepting Rhodes' donation. ${ }^{58}$ In 1910 Redmond was quoted in the 
newspapers as stating "We are entirely loyal to the empire as such, and we desire to strengthen the imperial bonds through a federal system of government". ${ }^{59}$ In the same year T.P. O'Connor wrote that apart from a few stubborn Unionists "we are all Imperial Federationists now". ${ }^{60}$ Although Rhodes favoured Irish home rule as a means of achieving Imperial federation there can be little doubt that Parnell, Redmond and O'Connor favoured Imperial federation as a means of achieving Irish home rule. None of the organisations that campaigned for Imperial federation ever succeeded in attracting a large membership within Ireland. In addition, the opinions expressed by Redmond and O'Connor could always be challenged by unionists on the grounds that they were not consistent with a substantial portion of nationalist opinion as represented by sections of the Irish media. ${ }^{61}$ It is likely that many Irish politicians saw this radical constitutional scheme as little more than a useful means of supporting their argument that Irish home rule would not harm the integrity of the British Empire and might even strengthen it.

Home rule all round did not become a reality in the late $19^{\text {th }}$ and early $20^{\text {th }}$ centuries. Devolved assemblies for Scotland, Wales and Northern Ireland were created in the 1990s but were the result of very different political circumstances to those that had existed before 1914. ${ }^{62}$ Irish supporters of home rule tended to offer limited support to calls for home rule all round for the same reasons that they offered lukewarm support for Imperial federation. Home rule all round helped to support the argument that calls for Irish autonomy were not incompatible with maintaining the integrity of the United Kingdom just as they were not incompatible with maintaining the integrity of the wider British Empire. Proposals for home rule all round could even be presented as offering a means of reinvigorating the union in providing new means of satisfying local sentiments. They were also seen as a means of freeing up the United Kingdom parliament at Westminster, which was often presented as overburdened with affairs that only related to particular parts of the United Kingdom, to deal with pressing matters of common interest. ${ }^{63}$

Yet, supporters of Irish home rule were careful not to link their own demands too closely to proposals for home rule all round. Proposals for home rule all round, like those for Imperial federation, might or might not become reality. Irish nationalists insisted that home rule for Ireland could not wait for the fulfilment of such proposals and had to be brought into being as soon as possible..$^{64}$ Unionists often argued that Irish nationalist interest in home rule all round was "merely a pretence" ${ }^{65}$ However, moderate Irish nationalists had good reason to doubt the strength of support for autonomous parliaments in Scotland and Wales, let alone England, in this period. In these circumstances, supporters of Irish home rule were adamant that Ireland's desire for autonomy could not wait for the peoples of other parts of the United Kingdom to come to similar conclusions. ${ }^{66} \mathrm{John}$ Redmond remained a strong supporter of home rule all round but insisted on a policy of "Home Rule for Ireland first". ${ }^{67}$ Irish nationalists were also wary of their country being offered a very limited form of autonomy which they feared might be acceptable to electorates in Scotland and Wales. ${ }^{68}$

Dominion status differed fundamentally from Imperial federation and home rule all round in that it was not a theoretical proposition but an established fact in the late $19^{\text {th }}$ century. It had been developed in Canada and was later exported to Australasia and southern Africa in the early $20^{\text {th }}$ century. Dominion status had a profound impact on Irish home rule in two different ways. First, from a strictly legal perspective, Dominion status heavily influenced the drafting of the legislation and proposed legislation containing 
schemes of Irish home rule. Secondly, it could be used to support the argument that selfgovernment would convert the Irish people away from hostility and into a position of genuine loyalty to the Empire, just as it had allegedly done in Canada. Yet Dominion status also proved to be an enduring source of confusion in the debates on Irish home rul e. As mentioned earlier, Irish politicians and political commentators tended to describe Dominion status and proposals for Irish home rule as if they were the same thing when they were not. This persistent confusion may have been based on ignorance and a loose use of language. Nevertheless, it raised suspicions amongst opponents of home rule that many Irish nationalists were actually aiming for a far greater position of autonomy than was strictly contained in the proposed legislation on Irish home rule. If home rule was treated as a path to Dominion status could Dominion status set out a path towards an Irish republic that would sever all ties with the United Kingdom and the British Empire? ${ }^{69}$ If Irish home rule had been put into practice before 1916 this kind of speculation would have been put to the test. The radicalisation of Irish politics after 1916 ensured that such matters would remain forever within the realm of conjecture.

The Irish home rule movement received a body blow in 1916 when an uprising by militant Irish nationalists created a new political movement that advocated total separation from the United Kingdom in place of home rule. In the general election of 1918 the oncedominant Irish parliamentary party was reduced a humiliating 6 seats out of a possible 105 available in Ireland. Proposals for home rule for Ireland and home rule all round faded into the background as a bitter paramilitary war took hold in Ireland between 1919 and 1921. An attempt to revive home rule was made in the Government of Ireland Act 1920 which created not one but two home rule parliaments, one in Belfast for the six counties that formed "Northern Ireland" and another for the twenty-six counties that formed "Southern Ireland". Only the institutions in Northern Ireland ever functioned and the conflict continued in most of the island. This period of unrest was finally resolved in late 1921 by the "Articles of Agreement for a Treaty between Great Britain and Ireland" signed by British and Irish representatives in London..$^{70}$ This agreement paved the way for the twenty-six counties of "Southern Ireland" to become the "Irish Free State" which would be awarded Dominion status. The new Irish Free State came into existence on 6 December 1922 as a Dominion, which meant that although its territory had seceded from the United Kingdom it remained an integral part of the British Empire. ${ }^{71}$ Northern Ireland remained firmly within the United Kingdom although it retained its home rule institutions including an autonomous government and parliament in Belfast.

Would a grant of Irish home rule in the late $19^{\text {th }}$ or early $20^{\text {th }}$ centuries have prevented most of the island from leaving the United Kingdom in 1922 or would events have followed a similar course to the history that is familiar to us? Such speculation can never be resolved and many would argue that there is little value in contemplating alternative histories. Nevertheless, many contemporaries who witnessed the birth of the Irish Free State in 1922 could not resist reflecting that home rule might have prevented the "United Kingdom of Great Britain and Ireland" from becoming the "United Kingdom of Great Britain and Northern Ireland". ${ }^{72}$ Andrew Bonar Law, the British Prime Minister who presided over the secession of most of the island of Ireland from the United Kingdom, could not resist such speculation when addressing the House of Commons in 1922:

It is quite possible, if we chose to turn our minds back, that if the country had followed Gladstone in 1886 this terrible misfortune, for it is nothing less, would have been cured, at any rate a generation ago. But is it quite possible ... if Gladstone had never raised the question, if it had not become a bone of contention between 
parties in this country, that just as for three generations there was the same feeling in Scotland against the Union as in Ireland, so in time Ireland, like Scotland, might have been willing to accept our good and evil fortunes as a full partner. There is no use thinking of that now. ${ }^{73}$

The Irish Free State pushed the boundaries of Dominion status and gradually dismantled the 1921 settlement in the years that followed. In 1937 the Irish Free State changed its name to "Ireland" and adopted a new constitution that claimed the territory of the entire island. ${ }^{74}$ Finally, in 1949 the Irish state became a republic and severed all connections with the Commonwealth. By contrast, Northern Ireland remained part of the United Kingdom with its home rule settlement undisturbed until the eruption of a new conflict brought direct rule from London in $1972 .{ }^{75}$ Nevertheless, between 1921 and 1972 home rule did become a reality for at least part of the island of Ireland, although not in a manner that Prime Minister Gladstone could ever have anticipated in the $1880 \mathrm{~s}$.

\section{BIBLIOGRAPHY}

\section{Primary sources}

Amery, L.S., "Home Rule and the Colonial Analogy" in S. Rosenbaum (ed.), Against Home Rule: The Case for the Union (London, Warne, 1912), pp. 128-52.

Butt, Isaac, Irish Federalism! Its Meaning, Its Objects and Its Hopes, 1st ed., (Dublin, Falconer, 1870)

Childers, Robert Erskine The Framework of Home Rule (London, Edward Arnold, 1911)

Dicey, A.V., "Home Rule from an English Point of View", Contemporary Review 42 (1882) 66-86

Dicey, A.V. Lectures Introductory to the Study of the Law of the Constitution, $2^{\text {nd }}$ ed., (London, Macmillan, 1886)

Dicey, A.V., England's Case against Home Rule, $3^{\text {rd }}$ ed. (London, Murray, 1887)

\section{Secondary sources}

Dictionary of Irish Biography, (Cambridge, Cambridge University Press, 2009)

Bell, Duncan, The Idea of Greater Britain - Empire and the Future of World Order, 1860-1900 (New Jersey, Princeton University Press, 2007)

Bew, Paul, John Redmond (Dublin: Historical Association of Ireland, 1996)

Byrne, Elaine, "Irish Home Rule - Stepping-Stone to Imperial Federation?" History Ireland 20(1)

(2012), pp. 25-7.

Ewart, Wilfred, A Journey in Ireland: 1921 (London, Putnam, 1922)

Gwynn, Denis, The Life of John Redmond (Edinburgh, Harrap, 1932) 
Hall, H. Duncan, The British Commonwealth of Nations - A Study of its Past and Future Development (London, Methuen, 1920)

Hall, H. Duncan, Commonwealth - A History of the British Commonwealth of Nations, (London, Van Nostrand Reinhold, 1971)

Kane, Nathan, A Study of the Debate on Scottish Home Rule, 1886-1914 (unpublished Ph.D thesis, University of Edinburgh, 2015).

Keith, A.B., Selected Speeches and Documents on British Colonial Policy, 1763-1917, Part II (Oxford University Press, 1961)

Kelly, James, "The making of law in eighteenth-century Ireland: the significance and import of Poynings' Law" in N.M. Dawson (ed.) Reflections on Law and History (Dublin, Four Courts Press, 2006) pp. 259-277

Kendle, John, The Colonial and Imperial Conferences 1887-1911 (London, Longmans, 1967)

Kendle, John, Ireland and the Federal Solution (Kingston and Montreal, McGill-Queen's, 1989)

Kendle, J.E., "The Round Table Movement and 'Home Rule All Round"', The Historical Journal, 11(2) (1968), pp. 332-53.

Kennedy, BA, "Sharman Crawford's Federal Scheme for Ireland" in HA Cronne et al (eds) Essays in British and Irish History (London, Muller, 1949), pp. 235-54.

Loughlin, James, Gladstone, Home Rule and the Ulster Question, 1882-93, (Dublin, Gill and Macmillan, 1986)

McIntyre, W. David, The Britannic Vision (London, Palgrave Macmillan, 2009)

Mohr, Thomas, "The Statute of Westminster: An Irish Perspective" Law and History Review 30(1) (2013), pp. 749-91

Mohr, Thomas, "The United Kingdom and Imperial Federation, 1900 to 1939: A Precedent for British Legal Relations with the European Union?" Comparative Legal History 4(2) (2016), pp. 1-31

Mohr, Thomas, “The Irish Question and the Evolution of British Imperial Law, 1916-1922" Dublin University Law Journal 39(2) (2016), pp. 405-428

Mohr, Thomas "The Impact of Canadian Confederation in Ireland" in Martel, M., J. Krikorian and A Schubert (eds), Globalizing Canadian Confederation - Canada and the World in 1867 (Toronto, University of Toronto, 2017), pp. 178-93.

Mohr, Thomas, "Law and the Foundation of the Irish State on 6 December 1922" Irish Jurist 59 (2018), pp. 31-58.

Morgan, Kenneth O., Wales in British Politics, 1868-1922 (Cardiff, University of Wales Press, 1963)

O’Day, Alan, Irish Home Rule, 1867-1921 (Manchester, Manchester University Press, 1998)

Pearl, Cyril, The Three Lives of Gavan Duffy (Sydney, New South Wales University Press, 1979)

Thornley, David, Isaac Butt and Home Rule (London, MacGibbon and Kee, 1964)

Wheatley, Michael, "John Redmond and federalism in 1910" Irish Historical Studies 32 (2001), pp. 343-64. 


\section{NOTES}

1. David Thornley, Isaac Butt and Home Rule (London, MacGibbon and Kee, 1964), pp. 91-4 and O’Day, Irish Home Rule, 1867-1921 (Manchester, Manchester University Press, 1998), pp. 28-32. Earlier proposals on Irish autonomy within the United Kingdom include that of William Sharman Crawford in the 1840s. See BA Kennedy, "Sharman Crawford's Federal Scheme for Ireland" in HA Cronne et al (eds), Essays in British and Irish History (London, Muller, 1949), pp. 235-54.

2. Isaac Butt, Irish Federalism! Its Meaning, Its Objects and Its Hopes, 1st ed., (Dublin, Falconer, 1870), pp. 11-12.

3. Alan O'Day, Irish Home Rule, pp. 38-41.

4. James Loughlin, Gladstone, Home Rule and the Ulster Question, 1882-93, (Dublin, Gill and Macmillan, 1986), pp. 35-52.

5. For example, see the views of Patrick James Smyth (1826-1885), an Irish home rule MP who consistently argued in favour of a return to Grattan's parliament in preference to any federal settlement, in "Rev Mr Galbraith on Federalism - Letter to the Editor" Irish Times, 3 December 1875, p. 6.

6. For a short biography of Henry Grattan (1746-1820) see Dictionary of Irish Biography, (Cambridge, Cambridge University Press, 2009), vol. 4, pp. 200-5. The autonomy enjoyed by Grattan's parliament owed a great deal to the abrogation of a statute known as Poynings' Law (10 Henry VII c.4 (Irl.)) whose provisions resulted in important limitations on the autonomy of the Irish parliament. See James Kelly, "The making of law in eighteenth-century Ireland: the significance and import of Poynings' Law" in N.M. Dawson (ed.) Reflections on Law and History (2006) p. 259-77.

7. Isaac Butt, Irish Federalism, pp. 34-35. For example, Grattan's parliament lacked a responsible executive and bills passed by Grattan's parliament still had to obtain the royal assent. Other limits on its autonomy are discussed in Robert Erskine Childers, The Framework of Home Rule (London, Edward Arnold, 1911), pp. 42-59.

8. British Library, Gladstone Papers, volume 587, MS 44672.

9. Thomas Mohr, "The Impact of Canadian Confederation in Ireland" in M. Martel, J. Krikorian and A Schubert (eds), Globalizing Canadian Confederation - Canada and the World in 1867 (Toronto, University of Toronto, 2017), pp. 185-7.

10. Isaac Butt, Irish Federalism!, p. 81.

11. Editorial, The Times, 16 April 1886, p. 9.

12. Section 1, Suspensory Act 1914 (UK).

13. Sections 3 and 5, British North America Act 1867 (UK)

14. Section 146, British North America Act 1867 (UK)

15. Duncan Hall, Commonwealth - A History of the British Commonwealth of Nations, (London, Van Nostrand Reinhold, 1971), p. 36

16. See Section 1, Statute of Westminster Act 1931 (UK). For unification with Canada see British North America Act 1949 (UK). This statute was renamed the "Newfoundland Act" in Canada under the Schedule to the Constitution Act 1982 (Canada).

17. Duncan Hall, Commonwealth, pp. 5-32.

18. Sir Thomas Inskip (1876-1947), attorney general of England and Wales (1928-1929) and (1932-1936) at Hansard, Parliamentary Debates (House of Commons), vol. 297, col. 1611, 11 February 1935.

19. Thomas Mohr, "The Statute of Westminster: An Irish Perspective" Law and History Review 30(1) (2013), p. 750.

20. Ibid. 
21. For example, Isaac Butt, Isaac, Irish Federalism!, p. 81 and Hansard, Parliamentary Debates, 10 May 1886, vol. 305, cols. 585-8; 7 June 1886, vol. 306, cols. 1221-30.

22. For example, see L. S. Amery, "Home Rule and the Colonial Analogy" in S. Rosenbaum (ed.), Against Home Rule: The Case for the Union (London, Warne, 1912), pp. 129-31. This confusion was epitomised by the frequent use of the hybrid term "Dominion home rule" by commentators of such diverse political views in the late $19^{\text {th }}$ and early $20^{\text {th }}$ centuries that its precise meaning was often rendered ambiguous. For example, see Wilfred Ewart, A Journey in Ireland: 1921 (London, Putnam, 1922), pp. 19, 36, 42-3, 61-2, 74, 83, 85-6, 114, 138 and 157. Erskine Childers used the equally confusing term "colonial home rule". For example, see Childers The Framework of Home Rule, p. 203.

23. “Mr T.P. O'Connor's Tour in Canada”, Freeman's Journal, 26 October 1910, p. 5.

24. For example, see Robert Erskine Childers, The Framework of Home Rule, pp. 198-203.

25. “Mr T.P. O'Connor's Tour in Canada”, Freeman's Journal, 26 October 1910, p. 5.

26. For example, see Duncan Bell, The Idea of Greater Britain - Empire and the Future of World Order, 1860-1900 (New Jersey, Princeton University Press, 2007) pp. 1-5.

27. W. David McIntyre, The Britannic Vision (London, Palgrave Macmillan, 2009), pp. 81-2 and John Kendle, Ireland and the Federal Solution (Kingston and Montreal, McGill-Queen's, 1989), p. 4.

28. Isaac Butt, Irish Federalism! pp. 14-6 and 60-2.

29. John Kendle, Ireland and the Federal Solution, pp. 88-90.

30. Denis Gwynn, The Life of John Redmond (Edinburgh, Harrap, 1932), p. 221 and Kendle, Ibid., p. 154.

31. Alan O’Day, Irish Home Rule, pp. 257-8.

32. A. V. Dicey, "Home Rule from an English Point of View", Contemporary Review 42 (1882), pp. 66-86.

33. A. V. Dicey, England's Case against Home Rule, $3^{\text {rd }}$ ed. (London, Murray, 1887), p. 54. See also J.E. Kendle, "The Round Table Movement and 'Home Rule All Round"', The Historical Journal, 11(2) (1968), p. 342.

34. Ibid., p. 196.

35. A.V. Dicey, Lectures Introductory to the Study of the Law of the Constitution, $2^{\text {nd }}$ ed., (London, Macmillan, 1886), p. 127.

36. A "Scottish Home Rule Association" was founded in 1886 and a Welsh equivalent called " Cymru Fydd", meaning "Young Wales", was also founded in 1886. These movements never enjoyed anything close to the electoral success enjoyed by the movement for Irish home rule. See John Kendle, Ireland and the Federal Solution, pp. 62, 64, 65, 71-2 and 103, Nathan Kane, A Study of the Debate on Scottish Home Rule, 1886-1914, (unpublished Ph.D thesis, University of Edinburgh, 2015) and Kenneth O. Morgan, Wales in British Politics, 1868-1922 (Cardiff, University of Wales Press, 1963). 37. John Kendle, Ireland and the Federal Solution, pp. 88-90.

38. Not all Imperial federalists agreed that the creation of a federal United Kingdom should be a preliminary to creating a federal British Empire. For example, Philip Kerr concluded "Federalism for the Empire, and Federalism for the United Kingdom are two entirely distinct ideas." It should also be remembered that some Imperial federalists were Unionists who opposed the principle of Irish home rule as a prelude to federalising the United Kingdom or the Empire: see J.E. Kendle, "The Round Table Movement and 'Home Rule All Round"', The Historical Journal, 11(2) (1968), pp. 339, 347-8 and 351.

39. Duncan Hall, The British Commonwealth of Nations - A Study of its Past and Future Development (London, Methuen, 1920), pp. 62-3.

40. Thomas Mohr, "The United Kingdom and Imperial Federation, 1900 to 1939: A Precedent for British Legal Relations with the European Union?" Comparative Legal History 4(2) (2016), pp. 1-31. 41. Cyril Pearl, The Three Lives of Gavan Duffy (Sydney, New South Wales University Press, 1979), p. 224.

Revue Française de Civilisation Britannique, XXIV-2 | 2019 
42. A. B. Keith, Selected Speeches and Documents on British Colonial Policy, 1763-1917, Part II (Oxford University Press, 1961), pp. 197-207.

43. Parliamentary Papers, 1897, Cmd. 8596, 15.

44. John Kendle, The Colonial and Imperial Conferences 1887-1911 (London, Longmans, 1967), pp. 39-52.

45. Thomas Mohr, "The United Kingdom and Imperial Federation", pp. 1-31

46. The National Archives of the United Kingdom (henceforth "TNA"), CO 886/5B, 2nd meeting, 25 May 1911.

47. Ibid.

48. The South African figure only took into account the white population of that Dominion (TNA, CO 886/5B, 2nd meeting, 25 May 1911).

49. John Kendle, Ireland and the Federal Solution, p. 58.

50. Ibid., p. 71.

51. Elaine Byrne, “Irish Home Rule - Stepping-Stone to Imperial Federation?" History Ireland 20(1) (2012), pp. 25-7.

52. “Mr. Redmond - Ireland's Defence”, Irish Independent, 15 March 1915, p. 5.

53. See also Butt, Irish Federalism, pp. 81-9; Gwynn, Life of John Redmond, pp. 50 and 55; Bew, John Redmond pp. 30-1 and Michael Wheatley, "John Redmond and federalism in 1910" Irish Historical Studies 32 (2001), p. 354.

54. “The National League”, Freeman's Journal, 9 September 1885, p. 2.

55. Duncan Hall, The British Commonwealth of Nations, p. 142.

56. Thomas Mohr, "The Irish Question and the Evolution of British Imperial Law, 1916-1922" Dublin University Law Journal 39(2) (2016), pp. 414-8.

57. TNA, CAB 32/1, $9^{\text {th }}$ Day, 16 April 1917.

58. Elaine Byrne, “Irish Home Rule”,pp. 25-7.

59. Michael Wheatley, "John Redmond and federalism in 1910", p. 354.

60. Ibid., p. 343.

61. Ibid., pp. 357-8.

62. Scotland Act 1998; Government of Wales Act 1998 and Northern Ireland Act 1998 (UK).

63. For example, see Butt, Irish Federalism, pp. 71-80 and Hansard, Parliamentary Debates (House of Commons), vol. 60, col 1432, 2 April 1914.

64. For example, Hansard, Parliamentary Debates (House of Commons), vol. 60, col. 1660, 6 April 1914 and Amery "Home Rule", p. 143.

65. L. S. Amery, "Home Rule and the Colonial Analogy", p. 144.

66. For example, Hansard, Parliamentary Debates (House of Commons), vol. 38, col. 106, 6 May 1912 and vol. 60, col. 1431-4, 2 April 1914. See also Robert Erskine Childers, The Framework of Home Rule, pp. 198-203.

67. "Nationalist Home Rule Demand", Irish Times, 19 October 1910, p. 7.

68. For example, Hansard, Parliamentary Debates (House of Commons), vol. 60, col. 1660, 6 April 1914.

69. See L. S. Amery, "Home Rule and the Colonial Analogy”, p. 142.

70. Second Schedule, Constitution of the Irish Free State (Saorstát Éireann) Act, 1922 (Ireland).

71. See Thomas Mohr, "Law and the Foundation of the Irish State on 6 December 1922" Irish Jurist 59 (2018), pp. 31-58.

72. Hansard, Parliamentary Debates (House of Commons), , vol. 159, col. 51, 23 November 1922.

73. Ibid. at 60-1.

74. Articles 2 and 3 of the original text of the 1937 Constitution. The territorial claim was removed by the Nineteenth Amendment of the Constitution Act 1998 (Ireland) 
75. The home rule institutions in Northern Ireland were suspended by Northern Ireland (Temporary Provisions) Act 1972 before being abolished by the Northern Ireland Constitution Act 1973 (UK).

\section{ABSTRACTS}

This article examines the meaning of Irish "home rule" as a constitutional experiment and its relationship with other proposals for constitutional change in the British Empire of the late $19^{\text {th }}$ and early $20^{\text {th }}$ centuries. The concept of Irish home rule was seen as a major constitutional experiment and the United Kingdom had little experience of devolution or federal settlements. This article will examine the model that was finally selected for this constitutional experiment which was inspired by the constitution of the Dominion of Canada. The article will also examine the relationship between Irish home rule and other constitutional experiments. These included proposals to create a federal United Kingdom, a concept known as "home rule all round" and even a federal British Empire, a concept known as "Imperial federation". The conclusion will assess the significance of these constitutional experiments in influencing the campaign for Irish home rule.

Cet article examine le sens que put avoir le «Home Rule» irlandais en tant qu'expérimentation constitutionnelle et sa relation avec d'autres propositions de changement constitutionnel dans l'Empire britannique à la fin du $\mathrm{XIX}^{\mathrm{e}}$ siècle et au début $\mathrm{du} \mathrm{XX}^{\mathrm{e}}$ siècle. Le concept de Home Rule irlandais fut considéré comme une expérimentation constitutionnelle majeure et le Royaume-Uni avait peu d'expérience en matière de dévolution et de fédéralisme. Cet article examine le modèle qui fut finalement retenu pour cette expérimentation inspirée par la constitution du Dominion du Canada. L'article étudie aussi la relation qui fut faite entre Home Rule irlandais et autres expérimentations constitutionnelles: celles-ci inclurent la proposition de créer un Royaume-Uni fédéral (connue sous le nom de «Home Rule All Round») et même d'établir un Empire britannique fédéral (projet connu sous le nom de "fédération impériale"). La conclusion évalue l'importance avec laquelle ces expérimentations constitutionnelles influencèrent la campagne menée en faveur du Home Rule irlandais.

\section{INDEX}

Mots-clés: Canada, Home Rule All Round, fédération impériale, dominion, empire britannique Keywords: Canada, home rule all round, imperial federation, dominion, British empire

\section{AUTHOR}

\section{THOMAS MOHR}

Thomas Mohr is an associate professor at the School of Law, University College Dublin. He is vice president of the Irish Legal History Society and book review editor of the Irish Jurist, Ireland's oldest law journal. His publications on Irish legal history range from medieval Gaelic law to the law of the independent Irish state in the 20th century. His latest book is Guardian of the Treaty - 
The Privy Council Appeal and Irish Sovereignty (Four Courts Press, 2016). This concerns an important aspect of Ireland's relationship with the British Empire in the inter-war years. He has also recently published on the disputed topic of determining Ireland's "independence day" in his article "Law and the Foundation of the Irish State on 6 December 1922", Irish Jurist (2018) pp. 31-58.

Thomas Mohr est enseignant-chercheur à la faculté de droit de University College Dublin. Il est vice-président de l'Irish Legal History Society et responsable des recensions dans l'Irish Jurist, la plus ancienne revue juridique d'Irlande. Ses publications sur l'histoire du droit en Irlande vont du droit gaélique médiéval au droit de l'Etat irlandais indépendant au XXe siècle. Son dernier ouvrage publié, Guardian of the Treaty - The Privy Council Appeal and Irish Sovereignty (Four Courts Press, 2016), porte sur un aspect important de la relation qui existait entre l'Irlande et l'empire britannique dans l'entre-deux-guerres. Plus récemment, dans un article intitulé "Law and the Foundation of the Irish State on 6 December 1922" paru dans l'Irish Jurist (2018, pp. 31-58), il s'est intéressé au sujet controversé de la date exacte de l'indépendance irlandaise. 